\title{
Regulatory mechanisms of $B$ cell responses and the implication in B cell-related diseases
}

\author{
Dong-Yan Tsai ${ }^{1 \dagger}$, Kuo-Hsuan Hung ${ }^{1 \dagger}$, Chia-Wei Chang ${ }^{1,2}$ and Kuo-I Lin ${ }^{1,2^{*}}$ (D)
}

\begin{abstract}
Terminally differentiated B cell, the plasma cell, is the sole cell type capable of producing antibodies in our body. Over the past 30 years, the identification of many key molecules controlling B cell activation and differentiation has elucidated the molecular pathways for generating antibody-producing plasma cells. Several types of regulation modulating the functions of the important key molecules in B cell activation and differentiation add other layers of complexity in shaping $B$ cell responses following antigen exposure in the absence or presence of $T$ cell help. Further understanding of the mechanisms contributing to the proper activation and differentiation of B cells into antibody-secreting plasma cells may enable us to develop new strategies for managing antibody humoral responses during health and disease. Herein, we reviewed the effect of different types of regulation, including transcriptional regulation, post-transcriptional regulation and epigenetic regulation, on B cell activation, and on mounting memory $B$ cell and antibody responses. We also discussed the link between the dysregulation of the abovementioned regulatory mechanisms and B cell-related disorders.
\end{abstract}

Keywords: B cell, Antibody, Plasma cell, Transcription factor, microRNA, Epigenetic regulation, B cell malignancy, Autoimmune disease

\section{Background}

The life journey of B cells - from development to activation and differentiation

$\mathrm{B}$ cell development begins in the fetal liver and continues in hematopoietic stem cells (HSCs) in the bone marrow where the stromal cells provide cytokines and chemokines, such as C-X-C motif chemokine 12 (CXCL12) and interleukin (IL)-7, for early stage B cell development [1]. The signals from the stromal cells allow HSCs to differentiate into common lymphoid progenitor cells (CLPs), which express c-kit and IL-7 receptors to provide the survival and proliferation signals for CLPs once they encounter the ligands. Upon expression of the transcription factors, E2A and early B-cell factor (EBF), CLPs further develop into pro-B cells [2]. Starting from pro-B cells, $B$ cells in the bone marrow experience

\footnotetext{
* Correspondence: kuoilin@gate.sinica.edu.tw

${ }^{\dagger}$ Dong-Yan Tsai and Kuo-Hsuan Hung contributed equally to this work.

${ }^{1}$ Genomics Research Center, Academia Sinica, 128 Academia Road, Sec. 2, Nankang Dist, Taipei 115, Taiwan

${ }^{2}$ Graduate Institute of Immunology, College of Medicine, National Taiwan University, Taipei 110, Taiwan
}

a sequential genetic rearrangement of heavy-chain and light-chain immunoglobulin genes, the $\mathrm{V}(\mathrm{D}) \mathrm{J}$ recombination, resulting in the generation of the IgM-expressing immature B cells [3]. The immature B cells migrate from the bone marrow to the spleen, where they further differentiate into T1 and T2 stages. B cells finally become mature $\mathrm{B}$ cells that co-express IgD and IgM, after which they wait to be activated by foreign antigens [4].

For activation and differentiation into antibody-secreting plasma cells, mature B cells in the periphery lymphoid organs require two signals. The first signal is derived from antigen-coupled B cell receptors (BCRs), and the second signal can be delivered in a $\mathrm{T}$ cell-dependent (TD) or T cell-independent (TI) manner. TI antigens, such as lipopolysaccharides (LPS) and glycolipids, mostly give rise to short-lived plasma cells that produce low-affinity antibodies. TD responses, initiated by antigen encounter and interaction with follicular helper $\mathrm{T}$ ( $\mathrm{Tfh}$ ) cells [5], allow B cells to either quickly become shortlived plasma cells or enter the germinal center $(\mathrm{GC})$ to differentiate into plasma cells or memory B cells with 
higher affinity toward the antigens. The GC can be polarized into the dark zone, where B cells undergo somatic hypermutation (SHM) at the variable regions of the $\mathrm{BCR}$ genes and clonal expansion, or the light zone, where $\mathrm{B}$ cells go through affinity maturation via interaction with Tfh cells and follicular dendritic cells (FDCs) to select B cell clones with high affinity BCRs [6]. Tfh cells produce the CD40 ligand for maintaining $\mathrm{B}$ cell survival, and IL-21 for promoting cell proliferation and differentiation [7]. In GC B cells, class switch recombination (CSR) that changes the constant region of the immunoglobulin from one isotype to another also occurs. GC B cells that are not positively selected by FDCs are eliminated by apoptosis, while the selected B cells may re-enter the dark zone to re-evolve BCRs with better affinity. The GC reaction allows $B$ cells with high affinity receptors to further differentiate into plasma cells or memory B cells [8]. The GC-derived plasma cells circulate to the bone marrow and secrete antigen-specific antibodies to become long-lived plasma cells that provide long-term protection against specific antigens [9].

\section{Main text}

Transcriptional network in mature B cells and plasma cells

$B$ cell differentiation is tightly controlled by a transcription regulation network. It involves the coordination of several transcription factors to promote the expression of antibody-secretion and plasma cell-related genes, and downregulate the B cell identity genes. B lymphocyte-induced maturation protein-1 (Blimp-1) is a critical transcription regulator of plasma cell formation, which mainly functions as a transcription repressor [10]. Deficiency in Blimp-1, encoded by the PR domain zinc finger protein 1 (Prdm1) gene, in mice impaired plasma cell differentiation, but did not affect B cell development [11]. Blimp-1 is expressed at low levels during the plasmablast stage, and at high levels in mature plasma cells [12]. Mechanistically, Blimp-1 represses the genes important for B cell identity, such as paired box protein 5 (PAX5), B-cell lymphoma-6 (BCL6) and BTB domain and $\mathrm{CNC}$ Homolog 2 (BACH2) [13, 14], and induces the activation of interferon regulatory factor 4 (IRF4) and $\mathrm{X}$ Box Binding Protein 1 (XBP-1) [15, 16], suggesting that it has a multifunctional role in transcription regulation. PAX5 is expressed throughout the early B cell developmental stages and in mature B cells, and is crucial for the maintenance of the identity of the B cell lineage [17]. Furthermore, it regulates the expression of BCR component genes, such as $C D 19, C D 21$ and $I g H$, and other transcription factors important for B cells, like IRF4, $I R F 8, B A C H 2$, Ikaros family zinc finger protein 3 (IKZF3) and PRDM1 [18]. After the B cells are activated and enter the GC B-cell stage in the secondary lymphoid organs, BCL6 and BACH2 expression begins.
Upregulation of BCL6 is critical for the formation of GC and the prevention of plasma cell differentiation $[19,20]$. Signaling through IL-21 receptor in proliferating GC B cells sustains the expression of BCL6 [21]. BACH2 is expressed in the pro- $\mathrm{B}$ to mature $\mathrm{B}$ cell stages, and is absent in plasma cells. Loss of BACH2 causes the lack of GC and Aicda, encoding activation-induced cytidine deaminase (AID), which is critical for SHM and CSR [22]. Both BCL6 and BACH2 suppress the expression of PRDM1 [23, 24]. In addition to Blimp-1, plasma cell formation requires IRF4, which represses Bcl6, therefore inducing Blimp-1 expression [25, 26]. Loss of IRF4 leads to impaired antibody production [27]. XBP-1 functions as a transcription regulator that is essential for Ig secretion and remodeling of the endoplasmic reticulum in plasma cells [28]. Absence of Blimp-1 causes impaired expression of XBP-1 and its downstream genes, suggesting that Blimp-1 is necessary for XBP-1 induction [29].

\section{miRNA in B cell activation and differentiation}

MicroRNAs (miRNAs) are small non-coding RNAs containing approximately 22-23 nucleotides (nts) in length that play important roles in post-transcriptional regulation in several biological processes, including apoptosis, cell proliferation, cell cycle, cell differentiation, hematopoiesis and cancer [30]. Studies on miRNA functions have revealed that one miRNA can specifically target hundreds of different mRNAs, and every single mRNA can be regulated by several different miRNAs [31, 32].

More than 1000 miRNAs have been identified in the human genome, which target about $60 \%$ of the human protein-encoding genes [33]. More than 100 different miRNAs are expressed by the immune system cells [34-36]. MiRNAs have the potential to broadly influence the molecular pathways that control the development and functions of innate and adaptive immune responses. Global miRNA expression profiling in various $B$ cell stages has been reported [37]. An atlas of human mature B cell miRNAs ("miRNome") was constructed with mature B cell line-specific short-RNA libraries coupled with low throughput sequencing [36]. Furthermore, miRNA array has been extensively used to identify miRNA expression profiles. For example, miRNA array profiling of $\mathrm{CD}^{+}$-activated and $\mathrm{CD}^{-}$-resting $B$ cells from human peripheral blood and tonsils revealed that 34 miRNAs were enriched in $\mathrm{CD}^{+}$-activated $\mathrm{B}$ cells, and eight of them, including miR-323, miR-138, miR-9*, miR-211, miR-129, miR-373, miR-135a and miR-184, were highly expressed miRNAs capable of co-targeting ZEB1 and TP53 [38]. The importance of miRNAs in B cell lineage was emphasized by a study on a mouse gene knockout model in which Dicer, encoding a key enzyme responsible for the generation of miRNAs from their precursors [39], is deleted in a B cell-specific manner. B cell-specific deletion of Dicer exhibited a developmental block at the pro-B to 
pre-B stages and revealed that miRNAs may have a role in controlling $\mathrm{V}(\mathrm{D}) \mathrm{J}$ recombination for generating antibody diversity in the early stage of B cell development [40].

We have investigated the changes in the miRNA expression inherent to the transcription network in plasma cell differentiation (Fig. 1) [41]. Two large scale analyses, deep-sequencing and miRNA microarray, were used to elucidate the changes in the expression of miRNAs during human plasma cell differentiation. In this study, human peripheral blood B cells were treated with the stimuli provided by Tfh-mimicking signals. Our computational analysis revealed that 34 and 60 miRNAs with significant reads were upregulated and downregulated, respectively, during human plasma cell differentiation. We characterized the relationship between differentially expressed miRNAs and transcription factors during plasma cell differentiation. We found that several differentially expressed miRNAs commonly target a single key transcription factor. We thus called these miRNAs a "miRNA hub". It is noteworthy that these miRNA hubs collaboratively regulate the expression of key transcription factors, thereby enabling the formation of human plasma cells in culture. Specifically, we found that upregulated miRNA hubs, including miR-34a-5p, miR-148a$3 p$, miR-183-5p and miR-365a-3p, directly repressed endogenous BCL6, BACH 2 and FOXP1 expression during plasma cell differentiation. However, downregulated
miRNA hubs, including miR-101-3p, miR-125b-5p and miR-223-3p, target the PRDM1 3' untranslated region (UTR). We further showed that NF-kB and PRDM1 contribute to the induction and repression of upregulated and downregulated miRNA hubs, respectively, during plasma cell differentiation. Moreover, our computational analysis unveiled that the transcription factor, FOXP1, is regulated by an induced miRNA hub and plays a role in prohibiting plasma cell differentiation.

With regard to the function of miRNAs in B cells, accumulating reports have demonstrated their roles in regulating $\mathrm{B}$ cell development and shaping the properties of the effector functions of B cells. One of the first miRNAs identified with functional significance to B cell development is miR-181a (now called miR-181a-5p). Overexpression of miR-181a-5p in HSCs increased the number of B cells in vitro and in vivo [42]. miR-181a-5p targets the differentiation inhibitor, ID2, which suppresses the early differentiation of B cells [43]. MiR-150 regulates the differentiation of normal $\mathrm{B}$ cells into antibody-secreting plasma cells. Several studies have indicated that miR-150 is highly expressed in mature B cells, relatively lowly expressed in immature $B$ cells, and has the lowest expression during the pro-B to pre-B cell transition $[44,45]$. One key target of miR-150 is $c-M y b$, which is required for the development of pro-B cells $[46$, 47]. Another study demonstrated that the p53-induced

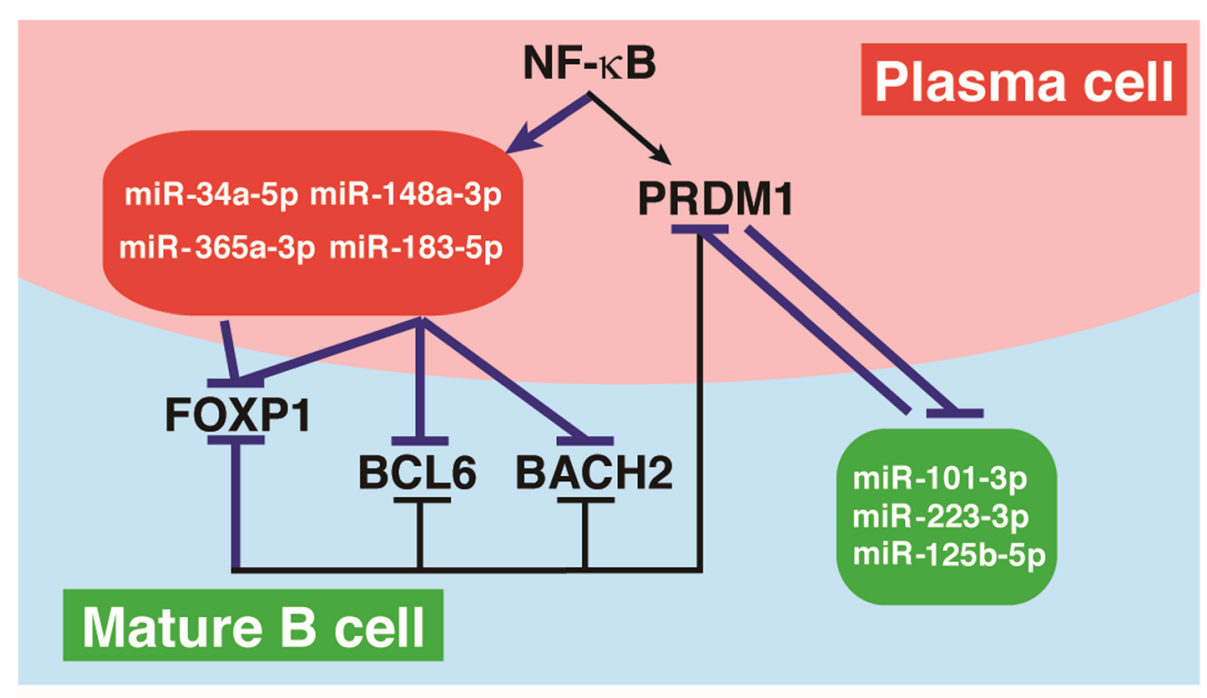

Up-regulated miRNA hub

Down-regulated miRNA hub

Fig. 1 The action of miRNAs and key transcription factors in coordinately directing plasma cell differentiation. Several factors are involved in the negative regulation of PRDM1 in mature $B$ cells, including BCL6/BACH2/FOXP1 and the miR-101-3p, miR-125b-5p, miR-223-3p miRNA hub. During B cell activation, NF-KB induces not only PRDM1 for the initiation of plasma cell differentiation, but also the miR-34a-5p, miR-148a-3p, miR-183-5p and miR$365 a-5 p$ hub. The induced miRNA hub including miR-34a-5p, miR-148a-3p, miR-183-5p and miR-365a-5p downregulates BCL6/BACH2/FOXP1, thereby establishing elevated levels of PRDM1 for driving plasma cell differentiation. Induced PRDM1 in turn suppresses the expression of the miR-101-3p, miR222-3p and miR-223-3p hub, and BCL6/BACH2/FOXP1, resulting in commitment to the plasma cell fate. Lines with arrow and bars indicate upregulation and downregulation, respectively. miRNAs in a red or green box represent upregulated or downregulated expression, respectively 
miRNA, miR-34a (now called miR-34a-5p), impaired B cell development. MiR-34a targets the 3'UTR of Forkhead box protein P1 (Foxp1) mRNA, which regulates the expression of recombination-activating genes (Rag1 and $R a g 2)$ in the pro-B to pre-B transition stages $[48,49]$. MiR-155 is a highly expressed miRNA in GC B cells, however it is expressed at relatively low levels in HSCs and mature B cells $[34,50]$. Knockout of the miR-155 gene in mice caused defective CSR and impaired differentiation of antibody-secreting plasma cells, by targeting Spi1 (encoding PU.1) and Aicda [51-53]. Besides miR155, miR-181b has been shown to negatively regulate CSR by targeting Aicda [54]. Additionally, several other studies have indicated that miR-9, miR-125b, the miR-1792 cluster and the miR-30 family are expressed in GC B cells and enhance plasma cell differentiation $[37,55]$. Deletion of the miR-17-92 cluster in B cells in mice caused enhanced homing of plasma cells to the bone marrow upon TD immunization, likely owing to the effect of miR17-92 on S1pr1, a gene important for the egress of lymphocytes from the lymphoid organs [56].

miRNAs in B cell malignancy and autoimmune diseases Lymphoma, including B and T-cell lymphoma, is malignancy of lymphatic cells, which affects more than a million people worldwide. Many miRNAs that contribute to B cell lymphomagenesis are also key regulators in normal hematopoiesis and lymphopoiesis. MiRNAs that affect tumorigenesis are called onco-miRs or tumor suppressor miRs $[57,58]$. The first reported onco-miR is miR-155, which is upregulated in normal plasma cell differentiation and overexpressed in several types of B cell lymphomas [59]. It is noteworthy that mice with miR155 overexpression in a B cell-specific manner develop high-grade B-cell lymphoma resembling diffuse large Bcell lymphoma (DLBCL) [59], likely owing to the effect of miR-155 on SHIP1, which promotes TNF $\alpha$-dependent cell proliferation [60]. MiR-155 is also a key regulator of the PI3K/AKT pathway in DLBCL. It promotes cell proliferation and inhibits apoptosis of DLBCL cells [61]. The most studied tumor-suppressor miRNA is miR-34a, which forms parts of the p53 network [62]. p53 directly induces miR-34a expression, but at the same time miR34a enhances p53 expression via inhibiting SIRT1, a regulator of $\mathrm{p} 53$ deacetylation, resulting in a positive feedback loop [63]. An additional study has shown that miR-34a reduces tumor growth in mice by targeting Foxp1 [64]. Another well-studied tumor-suppressor miRNA in B cell malignancy is miR-101 (now called miR-101-3p). The decreased expression of miR-101 correlated with the pathogenesis and prognosis of DLBCL, while upregulation of miR-101 in DLBCL inhibited cell proliferation and facilitated apoptosis by targeting MEK1 [65]. Furthermore, miR-183 is differentially expressed in the three Hodgkin's lymphoma (HL) subtypes and in $\mathrm{EBV}^{+}$and $\mathrm{EBV}^{-}$HLs. However, elucidation of the exact mode of action of miR-183 in HL requires further investigation [66]. Another study has shown that the expression of miR-223 and miR-125b in DLBCL is higher than in follicular lymphoma (FL), suggesting that the high expression of miR-223 and miR-125b may contribute to the transformation of DLBCL [67]. The aberrant expression of miR-125b in mantle cell lymphoma (MCL) has also been reported. A miRNA expression profile study was able to segregate MCLs into three different groups with distinct biological and clinical features [68].

Unlike DLBCL, which is usually formed from mutated or dysregulated normal GC B cells [69], multiple myeloma (MM) arises from malignant plasma cells in the bone marow [70, 71]. The molecular mechanisms underlying the dysregulation of p53 in MM have been intensively investigated for many years [72, 73]. Recently, it has been suggested that many miRNAs reported to negatively regulate p53 expression may also have implications in MM cells. For example, miR-125b is an onco$\mathrm{miR}$ in hematologic malignancies as it targets $p 53$ [74] and other components of the p53 pro-apoptotic network, including BAK1, PUMA, BMF, TRP53INP1 and Krupple-like factor 13 (KLF13) [75, 76]. Furthermore, dexamethasone induces the expression of miR-34a in MM cells [75, 77]. MiR-34a suppresses the expression of SIRT1 deacetylase, and thus allows the maintenance of acetylation and inactivation of $\mathrm{p} 53$. Results from a gene microarray study showed that the onco-miRs, miR-19b and miR-20a, were differently expressed in patients with MM and normal controls. MiR19b/20a promotes cell proliferation and migration, and inhibits cell apoptosis by targeting PTEN in patients with MM [78]. Moreover, miR-9 is another onco-miR that represses apoptosis in MM patients and MM cell lines by regulating the TRIM56/NF-кB pathway [79]. Taken together, these studies indicate the roles of miRNAs in the progression of B cell malignancy and their therapeutic potential for the treatment of B cell malignancy.

Recently, miRNAs have also been reported to play a role in immune dysfunction and autoimmune diseases. Systemic lupus erythematosus (SLE) is a multisystem autoimmune disorder that mostly affects women at childbearing age [80]. B cells play a cardinal role in the pathogenesis of SLE; more than 90\% of SLE patients have high levels of antinuclear antibodies in the sera, including anti-dsDNA antibodies and anti-snRNP antibodies [81]. Several miRNAs have been identified as biomarkers during the development of SLE. miRNA microarray analysis first revealed that miR-21 and miR17-5p are differently expressed in peripheral blood mononuclear cells (PBMCs) of SLE patients [82]. The increased expression of $\mathrm{miR}-7$ downregulates the 
expression of PTEN in B cells of SLE patients and contributes to hyper-activation of B cells [83]. Moreover, miR-17-5p is downregulated in PBMCs of SLE patients [82]. MiR-17-5p downregulates c-MYC expression during SLE formation. Transfection of miR-17-5p mimics into PBMCs from SLE patients caused a dramatic reduction in E2F1 and c-MYC expression, which resulted in reduced mRNA levels of the IFN-inducible gene, $M x A$ [84]. Screening of SLE-specific miRNAs from 42 B cellrelated miRNAs by a miRNA PCR Array identified that 14 miRNAs, including miR-103, miR-150, miR-20a, miR-223, miR-27, miR-15b, miR-16, miR-181a, miR-19b, miR-22, miR-23a, miR-25, miR-92a and miR-93, were significantly downregulated in the plasma of SLE patients, compared with the plasma of healthy donors [85]. Moreover, six plasma miRNAs, including miR-92a, miR27a, miR-19b, miR-23a, miR-223 and miR-16, were expressed at significantly decreased levels in SLE patients than in rheumatoid arthritis (RA) patients. These results demonstrated that these differentially expressed miRNAs in the plasma of SLE and RA patients can potentially be used as a diagnostic signature to distinguish between these two diseases. Another study using miRNA expression array revealed the serum miRNA expression profiles of SLE patients and healthy donors [86], showing that miR-371b-5p, miR-5100 and miR-146a-5p were increased in active SLE. These studies suggest the potential roles of these identified miRNAs in the development of SLE. The function of miRNAs in B cell malignancy and autoimmune diseases was summarized in Table 1.

\section{miRNA therapeutics}

MiRNA-targeted therapeutics can be divided into miRNA mimics [87] and inhibitors (also called antimiRs) [88]. The effect of modulation of miRNAs' levels on B cell malignancy has been demonstrated. Studies on a mouse model of miR-155-induced lymphoma, in which mir-155 is expressed under the control of doxycycline, demonstrated that doxycycline withdrawal resulted in suppression of mir-155 expression and subsequent tumor shrinkage [89]. In this mouse model, anti-miR155 treatment resulted in decreased tumor burden, indicating that miR-155 inhibition has therapeutic potential [89]. In contrast, miR-34a has been identified as a tumor suppressor miRNA by repressing several target genes, such as cyclin-dependent kinase 4 (CDK4), CDK6, BCL2, $M E T$, Notch, c-MYC, AXL and FOXP1 [48, 49, 90]. Several preclinical studies using miR-34 mimics have demonstrated their potential as anticancer therapeutics. For instance, miR-34a mimics showed promising anti-tumor activity in mouse models of lung [91], liver [92] and prostate [93] cancer. In these cases, significant inhibition of tumor growth was observed, which correlated with reduced expression of target proteins, such as c-MYC and BCL-2, in tumors. As a result of the above-mentioned studies, several miRNA-targeted therapeutics have reached clinical development. Currently, there are more than 20 clinical trials applying miRNA and siRNA-based therapeutics [94]. For instance, anti-miRs are singlestranded first-generation antisense oligonucleotides, which have been modified and designed to block the function of miRNAs. Anti-miRs with a 2'-O-methoxyethyl modification (2'-OM) are called antagomiRs [95]. These synthetic small RNA molecules have a complementary sequence to the target miRNA, and are able to strongly bind to the target miRNA and thereby block its function. MiRNA mimics are synthetic double-stranded small RNA molecules matching the corresponding miRNA sequence, and therefore functionally able to restore the loss of miRNA expression in diseases. MiR34a mimics reached phase I clinical trials for treating cancer, but this trial was halted at phase I owing to immune-related adverse events [94]. Effective delivery of RNA-based therapeutics to the target tissues has been a challenge in their therapeutic application [96]. Development of better in vivo delivery systems to reach the

Table 1 miRNAs in B cell malignancy and autoimmune diseases

\begin{tabular}{|c|c|c|c|c|}
\hline miRNA & Biological function & Target genes & Disease type & References \\
\hline miR-155 & Promote TNFa-dependent proliferation & SHIP1 & DCBCL & [60] \\
\hline miR-155 & Promote proliferation and inhibits apoptosis & PI3K/AKT pathway & $\mathrm{DCBCL}$ & [61] \\
\hline miR-101 & Inhibit proliferation and facilitate apoptosis & MEK1 & DCBCL & [65] \\
\hline $\operatorname{miR}-125 b$ & Inhibit apoptosis & p53 & MM & {$[74,75]$} \\
\hline miR-19b/20a & Promote proliferation, migration, and inhibit apoptosis & PTEN & MM & [78] \\
\hline miR-34a & Regulate cell cycle progression, cellular senescence and apoptosis & SIRT1 & MM & [77] \\
\hline miR-34a & Reduce tumor growth & Foxp1 & DLBCL & [49] \\
\hline miR-9 & Inhibit apoptosis & TRIM56/NF-kB pathway & MM & [79] \\
\hline miR-7 & Promote B cell hyperresponsiveness & PTEN & SLE & [83] \\
\hline miR-17-5p & Inhibit IFN-inducible gene & $c-M Y C$, and E2F1 & SLE & [84] \\
\hline
\end{tabular}


target specifically and efficiently to overcome the bottleneck of RNA-based therapy (including miRNA) in the clinic is the next important task.

\section{Epigenetic regulation in B cell activation and differentiation}

Epigenetic regulation is critical for coordination with the abovementioned transcription regulation networks in molecular programming during B cell activation and differentiation. The synergistic effects of both genetically and environmentally induced epigenetic modifications have been demonstrated to contribute to plasma cell differentiation and the etiopathogenetic mechanisms of the generation of B cell- or plasma cell-related diseases, such as autoimmune disorders and lymphomagenesis [97]. In general, the quiescent naïve B cells in peripheral lymphoid organs display inactive chromatin structures that show genome-wide DNA hypermethylation [98] and methylation of histone $3 \mathrm{~K} 9$ (H3K9) and H3K27 [99]. At this stage, the expression level of genes important for regulating $B$ cell identify and antigen recognition is regulated by histone deacetylase 7 (HDAC7) [100]. During early B cell development, HDAC7 represses myeloid and $T$ cell genes in early B cell progenitors [100]. Enhancer of zeste homolog 2 (Ezh2) is able to catalyze H3K27me3, which is associated with long-term repression [101]. In GC B cells, Ezh2 is highly expressed [102]. Deletion of $E z h 2$ in mice in a GC-specific manner caused impaired GC response, memory B cell formation and antibody responses compared with the control mice, suggesting that Ezh2 is essential for B cell functions [103]. In GC reactions, a number of histone modifications, including acetylated $\mathrm{H} 3$ and $\mathrm{H} 4$, and DNA double-strand breaks (DSBs)-induced phosphorylated $\mathrm{H} 2 \mathrm{AX}(\gamma \mathrm{H} 2 \mathrm{AX})$, are associated with CS $[104,105]$. However, acetylated H3 and H4 may not be linked with SHM activation. Instead, the histone modification pattern of SHM consists of phosphorylation of histone $\mathrm{H} 2 \mathrm{~B}$ on serine $14\left(\mathrm{H} 2 \mathrm{~B}^{\text {Ser14P }}\right)$, which is also responsive to DSBs [106].

In addition, in GC, the expression and action of AID is regulated by a series of epigenetic mechanisms. The suppression of Aicda in naïve B cells is due to DNA hypermethylation at the promoter region [107]. The H3 acetylation level of the Aicda gene locus in naïve B cells is low compared with the global H3 acetylation levels of other nearby genes. After B cells are stimulated, the Aicda gene locus is demethylated and becomes enriched with H3K4me3, H3K9ac and H3K14ac, which are associated with active histone marks [108]. Downregulation of Aicda in memory B cells and plasma cells may result from re-methylation of the Aicda gene locus. The histone chaperone, Spt6, regulates CSR and AID expression through two distinct types of histone modifications to generate the euchromatin status, namely, H3K4me3 and
H3K36me3, respectively. Spt6 is also required for the establishment of H3K4me3 marks in the IgH variable region during SHM [109]. In terms of the functional mode of action of AID, it interacts with ubiquitinated chromatin. Specifically, ubiquitination of H2BK120 and H2AK119 is colocalized with mismatched DNA polymerase $\eta$ in the AID-containing region [110].

The global levels of H3K9me2/me3 and H3K4me2 are all upregulated after LPS and IL-4 stimulation in a B cell culture [111]. We have also reported changes in histone modifications in B cells treated with Th cell-mimicking signals (Fig. 2) [99]. We found that the global levels of H3K9me3/me2 were reduced after stimulating mouse spleen B cells with Tfh cell-mediated signals. Furthermore, a systemic search of the epigenetic modifiers that contribute to the downregulation of $\mathrm{H} 3 \mathrm{~K} 9 \mathrm{me} 3 / \mathrm{me} 2$ revealed that the histone demethylases, KDM4A and KDM4C, were upregulated in mouse spleen B cells treated with Tfh cell-mimicking signals, whereas stimulation with LPS did not induce a similar pattern of KDM4A/KDM4C-mediated epigenetic changes. Functionally, depletion of KDM4A and KDM4C in response to Tfh cell-mimicking signals accelerated B cell activation and proliferation. Our genome-wide analysis using chromatin immunoprecipitation sequencing (ChIP-seq) combined with cDNA microarray analyses further revealed KDM4A and KDM4C targets during B cell activation. Among these, WDR5, an MLL complex member that facilitates H3K4 methylation [112], was further demonstrated to regulate the cell cycle; in particular, the cell cycle inhibitors, $C d k n 2$ and $C d k n 3$. Mechanistically, de novo motif analysis of the ChIP-seq data of KDM4A and $\mathrm{KDM} 4 \mathrm{C}$ revealed that NF- $\mathrm{KB}$ p65 interacts with $\mathrm{KDM} 4 \mathrm{~A}$ and $\mathrm{KDM} 4 \mathrm{C}$ to regulate gene expression, including WDR5.

Less is known about epigenetic modification during plasma cell differentiation. Genes expressed during plasma cell differentiation correlated with the acquisition of H3K4me1 and H3K4me3 histone marks, which are the markers of active promoters and distal enhancers [113]. Blimp-1 is a key transcription factor in directing plasma cell differentiation [15], thus, epigenetic regulation of PRDM1 expression and function would affect the humoral responses. BCL6 and HDAC4, -5 or -7 form stable complexes to mediate the decreased levels of histone acetylation on the PRDM1 promoter in GC B cells $[114,115]$. Furthermore, treatment of $B$ cells with HDAC inhibitors, such as trichostatin A (TSA) and butyrate, induced the expression of Blimp-1 and J chain, but decreased the expression of c-Myc and Pax-5. TSA treatment also promotes the expression of CD138 and downregulates surface IgM [116]. Several Blimp-1 target genes, including Pax5 and Spib, showed decreased histone acetylation in plasma cells $[117,118]$. Therefore, 


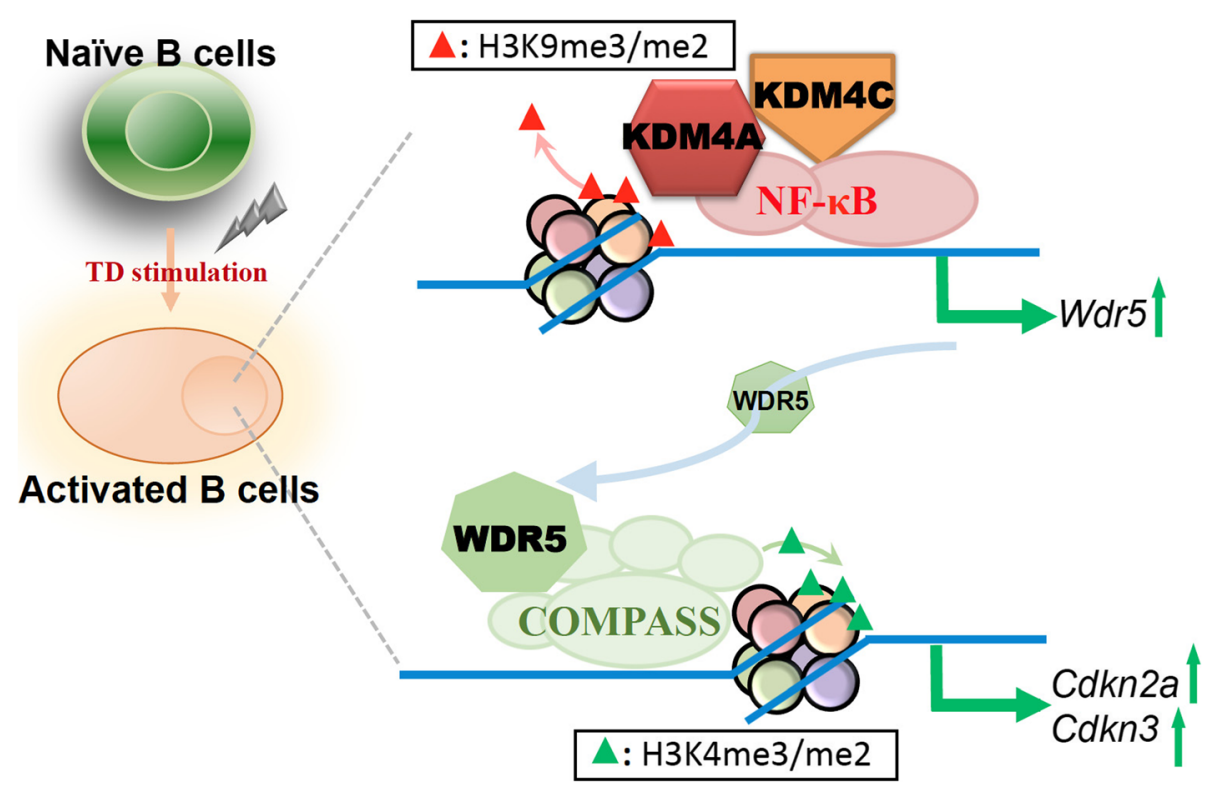

Fig. 2 Proposed model of the role of KDM4A and KDM4C in B cell activation. During activation by Tfh cell-mimicking signals, the induced demethylases, KDM4A and KDM4C, cooperate with NF-KB to upregulate the expression of Wdr5 by removing H3K9me3/me2. WDR5, a core subunit of the COMPASS histone H3K4 methyltransferase complex, in turn facilitates the transcription of Cdkn2a and Cdkn3 by elevating H3K4me3/me2. Both CDKN2A and CDKN3 are involved in the regulation of stimulated B cell proliferation

histone acetylation regulates the transcription of genes controlling B cell differentiation. In general, Blimp-1 is a transcription repressor able to recruit co-repressor proteins and histone modifiers to induce transcription repression. We have previously shown that a proline-rich domain of Blimp-1 directly interacts with LSD1, an H3K4me2/1 and H3K9me2/1-specific demethylase [117]. These proteins collaboratively remodel the chromatin accessibility of Blimp-1 targets, and thereby modulate the expression of Blimp-1 targets [117]. Disruption of the Blimp-1 interaction with LSD1, depletion of LSD1 expression and inhibition of LSD1 function all reduced the formation of antibody-secreting plasma cells. The five $\mathrm{C} 2 \mathrm{H} 2$ zinc fingers of Blimp-1 contain a nuclear localization signal and show DNA binding activity. They interact with HDAC2 [118] and H3K9-specific methyltransferase G9a [12], both of which are histone modifiers that facilitate the inactive chromatin and reduce transcription. These findings suggest that Blimp-1 regulates the differentiation of plasma cells by interacting with multiple chromatin modifiers.

Dysregulated epigenetic mechanisms in B cell malignancy and autoimmune diseases

The dysregulated epigenetic mechanism resulting in inadequate cell cycle is one of the major causes leading to malignant B cells. For instance, the H3K27-specific methyltransferase EZH2 is highly expressed in the GC, where it cooperates with Polycomb Repressive Complex2 (PRC2) [119]. Mutation of Ezh2 in mice resulted in
GC hyperplasia [120], which in part may stem from the enhanced repression of CDKN1A [120]. Furthermore, EZH2 can restrain plasma cell differentiation by establishing the H3K27me3 marks at the Prdm1 and Irf4 loci [103]. In human DLBCL cells, a mutant form of EZH2 silences PRDM1 through the recruitment of PRC2, resulting in the promotion of growth of the GC-type DLBCL [103]. Hence, 22\% of GC-type DLBCL cases carry EZH2 mutations [121]. In addition, KMT2D (also known as MLL2 or MLL4) is a member of the SET1 family of histone methyltransferases (HMTs) that facilitates the establishment of $\mathrm{H} 3 \mathrm{~K} 4 \mathrm{me} 2 / \mathrm{me} 1$ at enhancer regions and was frequently found to be mutated in FL (accounting for $70-80 \%$ of cases) and DLBCL [122124]. KMT2D regulates genes involved in the CD40, JAK-STAT, TLR and BCR signaling pathways [123]. Mice harboring a $K m t 2 d$ deletion in B cells showed B cell proliferation advantages and B cell lymphoproliferative diseases through collaboration with BCL-2 [124]. The CREBBP gene encodes a H3K18 and H3K27-specific lysine acetyltransferase that tags the transcription activation $[125,126]$. Further inactivating mutations and/or copy number losses of CREBBP occur in more than half of the FL cases and in nearly $20 \%$ of the DLBCL cases [127]. Accordingly, Crebbp deletion in the GC stage in mice in the presence of BCL-2 overexpression promotes the development of FL [128].

$\mathrm{MM}$ is plasma-cell malignancy with a slow progress feature [129]. One of the well studied HMTs in MM is the H3K36me2 and H4K20me2/me3-specific lysine 
methyltransferase, MMSET (also known as WHSC1 or NSD2) [130, 131]. MMEST is a DNA damage-responsive protein that catalyzes $\mathrm{H} 4 \mathrm{~K} 20$ methylation and induces the accumulation of 53BP1 at DNA damage sites [132]. Fifteen to $20 \%$ of MM cells carry the $t(4 ; 14)$ translocation, which generates the fusion of MMSET to the $\operatorname{IgH}$ locus, resulting in the upregulation MMSET, which correlates with poor prognosis [133]. MMSET forms a complex with epigenetic repressors by recruiting Sin3a, HDAC1, HDAC2 and the H3K4-specific demethylase, LSD1/KDM1A. The MMSET complex then indirectly induces c-MYC levels by repressing miR-126, thereby sustaining the proliferation of MM cells [134, 135]. Nevertheless, the $t[4,14]$ translocation in MM cells remodels the chromatin structure that carries the H3K36me2 histone activation mark and induces global reduction in $\mathrm{H} 3 \mathrm{~K} 27 \mathrm{me} 3$ by upregulating $\mathrm{EZH} 2$ at the oncogenic loci $[131,133]$. The extent of H3K27 methylation is associated with the malignancy of plasma cells. EZH2 is upregulated during MM progression [136], resulting in enhanced IL-6R expression, c-MYC activation, miR-26a downregulation and long non-coding RNA expression, thereby affecting the proliferation and apoptosis of MM cells [137, 138]. In contrast, mutations of the H3K27-specific demethylase, KDM6A, are found in $10 \%$ of primary MM samples [138, 139]. Inhibition of EZH2 decreases the growth of KDM6A-depleted MM cells. The KDM6A-mutated MM cells are more sensitive to EZH2 inhibitor-induced apoptosis through reactivation of BCL6 and subsequently repression of IRF4 and c$M Y C$ [140]. These results showed the synergetic effect of EZH2 and KDM6A, which collaboratively control the expression of a set of oncogenic genes. The levels of the H3K9-specific demethylase, KDM3A, have been demonstrated to be increased in MM cells. It has been shown that the KDM3A-KLF2-IRF4 axis promotes homing of $\mathrm{MM}$ cells to the bone marrow and their adherence to bone marrow stromal cells. KDM3A maintains the transcriptional activity of KLF2 and IRF4 [141, 142]. KDM3A is upregulated by hypoxia-induced HIF1 $\alpha$ that induces the expression of the long non-coding RNA, MALAT1, which in turn facilitates the upregulation of glycolytic and anti-apoptotic genes in MM cells [143, 144].

Recent reports have shown the significance of abnormal epigenetic regulation in the pathogenesis of SLE. A significantly reduced level of DNMT1 and DNMT3A transcripts was found in SLE patients compared with healthy controls [145]. The high IL-6 levels produced by SLE patients resulted in impaired induction of DNMT1, which in turn caused the demethylation of DNA in CpG islands in the cytoplasmic isoform of CD5, CD5-E1B. $\mathrm{CD} 5-\mathrm{E} 1 \mathrm{~B}$ is a negative regulator of $\mathrm{BCR}$ signaling, thereby establishing the immune tolerance in SLE B cells $[146$, 147]. Beyond the coding genes, the DNA methylation state of non-coding regions in the genome of SLE patients was also found to be altered. The hypomethylated long interspersed nuclear elements, but not the short interspersed nuclear elements, in SLE B cells correlate with the disease prognosis [148, 149]. Furthermore, our previously identified KDM4A/KDM4C/WDR5/CDKNs epigenetic pathway induced by Tfh cell-mimicking signals is dysregulated in B cells isolated from SLE patients [99]. We found that activated normal human peripheral blood $\mathrm{B}$ cells exhibited a significant reduction in $\mathrm{H} 3 \mathrm{~K} 9 \mathrm{me} 2$ and $\mathrm{H} 3 \mathrm{~K} 9 \mathrm{me} 3$, while the levels of H3K9me2 and H3K9me3 in stimulated SLE B cells did not change significantly. Accordingly, KDM4A and $K D M 4 C$ mRNA levels were significantly reduced in the steady state and the stimulated SLE B cells, compared with normal B cells. Together, the effects of dysregulated histone modifiers on $B$ cell malignancy and autoimmune diseases were summarized in Table 2.

\section{Epigenetic therapeutics}

The aberrant epigenetic profiles of malignant cells, such as in MM, have been established in past decade. To target these aberrant epigenetic regulation mechanisms in MM, there are three categories of epigenetic modulating therapeutic agents under development: DNA methyltransferase inhibitors (DNMTi), histone deacetylase inhibitors (HDACi) and histone lysine methyltransferase inhibitor (HKMTi). Several DNMTis, such as 5-azacytidine (AZA, Vidaza) and 2-deoxy-5-aza-cytidine (DAC, Decitabine, Dacogen), have been ideal therapeutics for myelodysplastic syndrome [150, 151]. In MM, AZA and DAC have been demonstrated to have anti-MM effects, which cause cell cycle arrest and generation of oxidative stress to induce necrosis and apoptosis [152, 153]. In recent years, great progress has been achieved with HDACis in drug development for cancer therapy. The anti-MM effects of HDACis rely on their chromatin remodeling activity to induce apoptosis, cell cycle arrest and autophagy, as well as to suppress angiogenesis [154]. In particular, HDAC6 regulates deacetylation of $\alpha$-tubulin and heat shock protein $90 \alpha$ (HSP90 $\alpha$ ), thereby affecting cell motility and cell adhesion, as well as the aggresome degradation pathway in response to misfolded proteins in MM cells [155]. Furthermore, inhibition of HDAC6 shows minimal side effects on healthy cells [156]. Hence, several clinical trials have applied HDAC6-specific inhibitors, such as Rocilinostat [157], ITF2357 [158] and Panobinostat [159, 160], in MM therapy.

The bromodomain (BRD) and extra-terminal (BET) family of BRD-containing proteins is a group of proteins that recognize acetylated lysine residues of histones and regulate gene expression. Hence, suppression of the activity of BRD-containing proteins is an effective way to control the histone-acetylation-dependent gene activation. The pan-BET inhibitor, GSK525762, inhibits growth of a 
Table 2 Epigenetic controls in B cell malignancy and autoimmune diseases

\begin{tabular}{|c|c|c|c|c|}
\hline $\begin{array}{l}\text { Histone } \\
\text { Modifier }\end{array}$ & Biological function & $\begin{array}{l}\text { Target genes } \\
\text { (direct or indirect) }\end{array}$ & Disease type & References \\
\hline $\mathrm{EZH} 2$ & Promote growth & CDKN1A & DCBCL & [120] \\
\hline $\mathrm{EZH} 2$ & Retrain plasma cell differentiation & PRDMI and IRF4 & $\begin{array}{l}\text { Non-Hodgkin } \\
\text { lymphomas }\end{array}$ & [103] \\
\hline KDM4A & $\begin{array}{l}\text { Promote } B \text { cell activation and } \\
\text { differentiation }\end{array}$ & WDR5 & SLE & [99] \\
\hline KDM4C & $\begin{array}{l}\text { Promote } B \text { cell activation and } \\
\text { differentiation }\end{array}$ & WDR5 & SLE & [99] \\
\hline LSD1 & Promote differentiation & Blimp-1 targets, such as CIITA and c-MYC & MM & [117] \\
\hline MMSET & Promote growth & $c-M Y C$ & MM & [135] \\
\hline KDM6A & Promote oncogenesis & $B C L-6, I R F 4$ and $c-M Y C$ & MM & [140] \\
\hline KDM3A & Promote homing of MM cells & $K L F 2$, and IRF4 & MM & [141] \\
\hline WDR5 & Inhibit proliferation & CDKN2, and CDKN3 & SLE & [99] \\
\hline CREBBP & Regulate GC reaction and proliferation & $\mathrm{BCL}-6$ targets, such as $B C L-2$ and $P R D M 1$ & $\mathrm{FL}$ and $\mathrm{DCBCL}$ & [128] \\
\hline KMT2D & Repress lymphoma development & $\begin{array}{l}\text { Genes in CD40, JAK-STAT, TLR and BCR } \\
\text { pathways }\end{array}$ & FL and DCBCL & [123] \\
\hline DNMT1 & Promote BCR signaling & CD5, and CD5-E1B & SLE & [146] \\
\hline
\end{tabular}

broad spectrum of human hematological cancer cells, including MM [161]. Other ongoing clinical studies showed that BET inhibitors, such as OTX015 and CPI-0610, which selectively block BRD2, BRD3 and BRD4, were also used in the pre-clinical or clinical trials for MM or lymphoma $[162,163]$.

In addition, EZH2 inhibitors have been developed to block MM. Currently, the EZH2 inhibitor, Tazemetostat (EPZ-6438), is under clinical trials in combination with immunomodulatory imide drugs (IMiDs) for treating a subgroup of MM patients [164]. GSK2816126, another EZH2 inhibitor, is also in clinical trials for MM. It induces apoptosis in MM cells by downregulating mitochondrial activity [165].

\section{Conclusions}

Accumulating research efforts have been made to elucidate the molecular pathways regulating the $\mathrm{B}$ cell responses and antibody production. Studying the regulatory mechanisms of $\mathrm{B}$ cell responses has become an emerging research topic with the need to further understand the pathways that control the new coming pathogens through vaccination or to combat cancers. In addition to the above-described regulatory mechanisms in B cell activation and differentiation, there are other types of regulation involved, such as glycosylation and SUMOylation. Studies on these regulatory mechanisms open opportunities for identifying new druggable targets to control B cell-related diseases such as autoimmune diseases and B cell malignancies.

\section{Abbreviations}

2'-OM: 2'-O-methoxyethyl; AID: Activation induced cystidine deaminase; ASOs: Antisense oligonucleotides; $\mathrm{BACH} 2$ : BTB domain and $\mathrm{CNC}$ homologue 2; BCL6: B-cell lymphoma 6; BCRs: B cell receptors; BET: Bromodomain extra- terminal; Blimp-1: B lymphocyte-induced maturation protein-1; BRD: Bromodomain; CDK4: Cyclin-dependent kinase 4; CDK6: Cyclindependent kinase 6; CLPs: Common lymphoid progenitors; CSR: Class switch recombination; DLBCL: Diffuse large B-cell lymphoma; DNMTi: DNA methyltransferase inhibitors; EBF: Early B-cell factor; ER: Endoplasmic reticulum; Ezh2: Enhancer of zeste homolog 2; FDCs: Follicular dendritic cells; FL: Follicular lymphoma; FOXP1: Forkhead box protein P1; GC: Germinal center; H3K27: methylation of histone 3 K27; H3K9: methylation of histone 3 K9; HDAC7: Histone deacetylase 7; HDACi: Histone deacetylase inhibitor; HKMTi: Histone lysine methyltransferase inhibitor; HL: Hodgkin's lymphoma; HMTs: Histone methyltransferases; HSCs: Hematopoietic stem cells; IKZF3: Ikaros family zinc finger protein 3; IMiDs: Immunomodulatory imide drugs; IRF4: Interferon-regulatory factor 4; IRF8: Interferon-regulatory factor 8; KLF13: Krupple-like factor 13; LPS: Lipopolysaccharides; MCL: Mantle cell lymphoma; miRNA: microRNA; MM: Multiple myeloma; MMSET: H4K20me2/ me3-specific lysine methyltransferase; PAX5: Paired box gene 5: PBMCs: Peripheral blood mononuclear cells; PRC2: Polycomb Repressive Complex-2; PRDM1: PR domain zinc finger protein 1; RA: Rheumatoid arthritis; RAG-1: Recombination-activating gene-1; RAG-2: Recombinationactivating gene-2; SHM: Somatic hypermutation; SLE: Systemic lupus erythematosus; TD: T-cell dependent; Tfh: follicular helper T; TI: T-cell independent; TSA: Trichostatin A; XBP-1: X-box-binding protein 1

\section{Acknowledgements}

Not applicable.

\section{Authors' contributions}

DYT, KHH, CWC and KIL wrote the manuscript. All authors read and approved the final manuscript.

\section{Funding}

This work was supported by grants from the Taiwan Bio-Development Foundation, Ministry of Science and Technology (MOST 106-2320-B-001-011-MY3 and MOST 107-0210-01-19-01), National Health Research Institute (NHRIEX108-10835SI) and Academia Sinica (AS-IA-107-L05).

Availability of data and materials

Not applicable.

Ethics approval and consent to participate Not applicable. 


\section{Consent for publication}

Not applicable.

\section{Competing interests}

The authors declare that they have no competing interests.

Received: 13 June 2019 Accepted: 22 August 2019

Published online: 01 September 2019

\section{References}

1. Nagasawa T. The chemokine CXCL12 and regulation of HSC and B lymphocyte development in the bone marrow niche. Adv Exp Med Biol. 2007:602:69-75.

2. O'Riordan $M$, Grosschedl R. Coordinate regulation of $B$ cell differentiation by the transcription factors EBF and E2A. Immunity. 1999;11(1):21-31.

3. Krangel MS. Gene segment selection in V(D)J recombination: accessibility and beyond. Nat Immunol. 2003;4(7):624-30.

4. Chung JB, Silverman M, Monroe JG. Transitional B cells: step by step towards immune competence. Trends Immunol. 2003;24(6):343-9.

5. Nutt SL, Hodgkin PD, Tarlinton DM, Corcoran LM. The generation of antibody-secreting plasma cells. Nat Rev Immunol. 2015;15(3):160-71.

6. Manser T. Textbook Germinal Centers? J Immunol. 2004;172(6):3369-75.

7. Bishop GA, Hostager BS. Signaling by CD40 and its mimics in B cell activation. Immunol Res. 2001;24(2):97-109.

8. Phan TG, Paus D, Chan TD, Turner ML, Nutt SL, Basten A, et al. High affinity germinal center $B$ cells are actively selected into the plasma cell compartment. J Exp Med. 2006;203(11):2419-24.

9. Kurosaki T, Kometani K, Ise W. Memory B cells. Nat Rev Immunol. 2015;15(3): 149-59.

10. Shaffer AL, Lin K-I, Kuo TC, Yu X, Hurt EM, Rosenwald A, et al. Blimp-1 orchestrates plasma cell differentiation by extinguishing the mature $B$ cell gene expression program. Immunity. 2002;17(1):51-62.

11. Shapiro-Shelef M, Lin K-I, McHeyzer-Williams LJ, Liao J, McHeyzer-Williams MG, Calame K. Blimp-1 is required for the formation of immunoglobulin secreting plasma cells and pre-plasma memory B cells. Immunity. 2003; 19(4):607-20.

12. Gyory I, Wu J, Fejer G, Seto E, Wright KL. PRDI-BF1 recruits the histone H3 methyltransferase G9a in transcriptional silencing. Nat Immunol. 2004;5(3): 299-308.

13. Lin K-I, Angelin-Duclos C, Kuo TC, Calame K. Blimp-1-dependent repression of Pax -5 is required for differentiation of B cells to immunoglobulin Msecreting plasma cells. Mol Cell Biol. 2002;22(13):4771-80.

14. Vasanwala FH, Kusam S, Toney LM, Dent AL. Repression of AP-1 function: a mechanism for the regulation of Blimp-1 expression and B lymphocyte differentiation by the B cell lymphoma-6 protooncogene. J Immunol. 2002; 169(4):1922-9

15. Minnich M, Tagoh H, Bonelt P, Axelsson E, Fischer M, Cebolla B, et al. Multifunctional role of the transcription factor Blimp-1 in coordinating plasma cell differentiation. Nat Immunol. 2016;17(3):331-43.

16. Tellier J, Shi W, Minnich M, Liao Y, Crawford S, Smyth GK, et al. Blimp-1 controls plasma cell function through the regulation of immunoglobulin secretion and the unfolded protein response. Nat Immunol. 2016;17(3):323-30.

17. Cobaleda C, Schebesta A, Delogu A, Busslinger M. Pax5: the guardian of B cell identity and function. Nat Immunol. 2007;8(5):463-70.

18. Horcher M, Souabni A, Busslinger M. Pax5/BSAP maintains the identity of B cells in late B Lymphopoiesis. Immunity. 2001;14(6):779-90.

19. Dent AL, Shaffer AL, Yu X, Allman D, Staudt LM. Control of inflammation, cytokine expression, and germinal center formation by BCL-6. Science. 1997; 276(5312):589-92.

20. Cattoretti G, Chang CC, Cechova K, Zhang J, Ye BH, Falini B, et al. BCL-6 protein is expressed in germinal-center B cells. Blood. 1995;86(1):45-53.

21. Linterman MA, Beaton L, Yu D, Ramiscal RR, Srivastava M, Hogan JJ, et al. IL21 acts directly on $\mathrm{B}$ cells to regulate $\mathrm{BCl}-6$ expression and germinal center responses. J Exp Med. 2010;207(2):353-63.

22. Muto A, Tashiro S, Nakajima O, Hoshino H, Takahashi S, Sakoda E, et al. The transcriptional programme of antibody class switching involves the repressor Bach2. Nature. 2004;429(6991):566-71.

23. Tunyaplin C, Shaffer AL, Angelin-Duclos CD, Yu X, Staudt LM, Calame KL. Direct repression of prdm1 by Bcl-6 inhibits plasmacytic differentiation. J Immunol. 2004;173(2):1158-65.
24. Ochiai K, Katoh Y, Ikura T, Hoshikawa Y, Noda T, Karasuyama H, et al. Plasmacytic transcription factor Blimp-1 is repressed by Bach2 in B cells. J Biol Chem. 2006;281(50):38226-34.

25. Angelin-Duclos C, Cattoretti G, Lin Kl, Calame K. Commitment of B lymphocytes to a plasma cell fate is associated with Blimp-1 expression in vivo. J Immunol. 2000;165(10):5462-71.

26. Falini B, Fizzotti M, Pucciarini A, Bigerna B, Marafioti T, Gambacorta M, et al. A monoclonal antibody (MUM1p) detects expression of the MUM1/RF4 protein in a subset of germinal center B cells, plasma cells, and activated T cells. Blood. 2000;95(6):2084-92.

27. Mittrucker HW, Matsuyama T, Grossman A, Kundig TM, Potter J, Shahinian A, et al. Requirement for the transcription factor LSIRF/RF4 for mature B and T lymphocyte function. Science. 1997;275(5299):540-3.

28. Reimold AM, Iwakoshi NN, Manis J, Vallabhajosyula P, Szomolanyi-Tsuda E, Gravallese EM, et al. Plasma cell differentiation requires the transcription factor XBP-1. Nature. 2001;412(6844):300-7.

29. Shaffer AL, Shapiro-Shelef M, Iwakoshi NN, Lee A-H, Qian S-B, Zhao H, et al. XBP1, downstream of Blimp-1, expands the secretory apparatus and other organelles, and increases protein synthesis in plasma cell differentiation. Immunity. 2004;21(1):81-93.

30. Huang Y, Shen XJ, Zou Q, Zhao QL. Biological functions of microRNAs. Bioorg Khim. 2010;36(6):747-52.

31. Selbach M, Schwanhausser B, Thierfelder N, Fang Z, Khanin R, Rajewsky N. Widespread changes in protein synthesis induced by microRNAs. Nature. 2008;455(7209):58-63.

32. Zhao G, Yu D, Weiss MJ. MicroRNAs in erythropoiesis. Curr Opin Hematol. 2010;17(3):155-62.

33. Hogg DR, Harries LW. Human genetic variation and its effect on miRNA biogenesis, activity and function. Biochem Soc Trans. 2014;42(4):1184-9.

34. Georgantas RW 3rd, Hildreth R, Morisot S, Alder J, Liu CG, Heimfeld S, et al. CD34+ hematopoietic stem-progenitor cell microRNA expression and function: a circuit diagram of differentiation control. Proc Natl Acad Sci U S A. 2007;104(8):2750-5.

35. Guo S, Lu J, Schlanger R, Zhang H, Wang JY, Fox MC, et al. MicroRNA miR125 a controls hematopoietic stem cell number. Proc Natl Acad Sci U S A. 2010;107(32):14229-34.

36. Basso K, Sumazin P, Morozov P, Schneider C, Maute RL, Kitagawa Y, et al. Identification of the human mature B cell miRNome. Immunity. 2009;30(5): $744-52$.

37. Zhang J, Jima DD, Jacobs C, Fischer R, Gottwein E, Huang G, et al. Patterns of microRNA expression characterize stages of human B-cell differentiation. Blood. 2009;113(19):4586-94.

38. Malpeli G, Barbi S, Zupo S, Tosadori G, Scardoni G, Bertolaso A, et al. Identification of microRNAs implicated in the late differentiation stages of normal B cells suggests a central role for miRNA targets ZEB1 and TP53. Oncotarget. 2017;8(7):11809-26.

39. Tijsterman M, Ketting RF, Plasterk RH. The genetics of RNA silencing. Annu Rev Genet. 2002;36:489-519.

40. Koralov SB, Muljo SA, Galler GR, Krek A, Chakraborty T, Kanellopoulou C, et al. Dicer ablation affects antibody diversity and cell survival in the $B$ lymphocyte lineage. Cell. 2008;132(5):860-74.

41. Tsai DY, Hung KH, Lin IY, Su ST, Wu SY, Chung CH, et al. Uncovering MicroRNA regulatory hubs that modulate plasma cell differentiation. Sci Rep. 2015;5:17957.

42. Chen CZ, Li L, Lodish HF, Bartel DP. MicroRNAs modulate hematopoietic lineage differentiation. Science. 2004;303(5654):83-6.

43. Jensen K, Brusletto BS, Aass HC, Olstad OK, Kierulf P, Gautvik KM. Transcriptional profiling of mRNAs and microRNAs in human bone marrow precursor B cells identifies subset- and age-specific variations. PLoS One. 2013;8(7):e70721.

44. Vasilatou D, Papageorgiou S, Pappa V, Papageorgiou E, Dervenoulas J. The role of microRNAs in normal and malignant hematopoiesis. Eur J Haematol. 2010;84(1):1-16.

45. Zhou B, Wang S, Mayr C, Bartel DP, Lodish HF. miR-150, a microRNA expressed in mature B and T cells, blocks early B cell development when expressed prematurely. Proc Natl Acad Sci U S A. 2007;104(17):7080-5.

46. Xiao C, Calado DP, Galler G, Thai TH, Patterson HC, Wang J, et al. MiR-150 controls B cell differentiation by targeting the transcription factor c-Myb. Cell. 2007;131(1):146-59.

47. Fahl SP, Crittenden RB, Allman D, Bender TP. C-Myb is required for pro-B cell differentiation. J Immunol. 2009;183(9):5582-92. 
48. Rao DS, O'Connell RM, Chaudhuri AA, Garcia-Flores Y, Geiger TL, Baltimore D. MicroRNA-34a perturbs B lymphocyte development by repressing the forkhead box transcription factor Foxp1. Immunity. 2010;33(1):48-59.

49. Craig VJ, Cogliatti SB, Imig J, Renner C, Neuenschwander S, Rehrauer H, et al. Myc-mediated repression of microRNA-34a promotes high-grade transformation of B-cell lymphoma by dysregulation of FoxP1. Blood. 2011; 117(23):6227-36

50. O'Connell RM, Chaudhuri AA, Rao DS, Gibson WS, Balazs AB, Baltimore D. MicroRNAs enriched in hematopoietic stem cells differentially regulate longterm hematopoietic output. Proc Natl Acad Sci U S A. 2010;107(32):1423540.

51. Rodriguez A, Vigorito E, Clare S, Warren MV, Couttet P, Soond DR, et al. Requirement of bic/microRNA-155 for normal immune function. Science. 2007;316(5824):608-11.

52. Thai TH, Calado DP, Casola S, Ansel KM, Xiao C, Xue Y, et al. Regulation of the germinal center response by microRNA-155. Science. 2007;316(5824): 604-8.

53. Vigorito E, Perks KL, Abreu-Goodger C, Bunting S, Xiang Z, Kohlhaas S, et al. microRNA-155 regulates the generation of immunoglobulin class-switched plasma cells. Immunity. 2007;27(6):847-59.

54. Timmer AM, Nizet $\mathrm{V}$. IKKbeta/NF-kappaB and the miscreant macrophage. J Exp Med. 2008;205(6):1255-9.

55. Malumbres R, Sarosiek KA, Cubedo E, Ruiz JW, Jiang X, Gascoyne RD, et al. Differentiation stage-specific expression of microRNAs in $B$ lymphocytes and diffuse large B-cell lymphomas. Blood. 2009;113(16):3754-64.

56. Xu S, Ou X, Huo J, Lim K, Huang Y, Chee S, et al. Mir-17-92 regulates bone marrow homing of plasma cells and production of immunoglobulin G2C. Nat Commun. 2015;6:6764

57. Lu J, Getz G, Miska EA, Alvarez-Saavedra E, Lamb J, Peck D, et al. MicroRNA expression profiles classify human cancers. Nature. 2005;435(7043):834-8.

58. Thomson JM, Newman M, Parker JS, Morin-Kensicki EM, Wright T, Hammond SM. Extensive post-transcriptional regulation of microRNAs and its implications for cancer. Genes Dev. 2006;20(16):2202-7.

59. Costinean S, Zanesi N, Pekarsky Y, Tili E, Volinia S, Heerema N, et al. Pre-B cell proliferation and lymphoblastic leukemia/high-grade lymphoma in $E(\mathrm{mu})$ miR155 transgenic mice. Proc Natl Acad Sci U S A. 2006;103(18):7024-9.

60. Pedersen IM, Otero D, Kao E, Miletic AV, Hother C, Ralfkiaer E, et al. OncomiR-155 targets SHIP1 to promote TNFalpha-dependent growth of B cell lymphomas. EMBO Mol Med. 2009;1(5):288-95.

61. Huang $X$, Shen $Y$, Liu M, Bi C, Jiang C, lqbal J, et al. Quantitative proteomics reveals that miR-155 regulates the PI3K-AKT pathway in diffuse large B-cell lymphoma. Am J Pathol. 2012;181(1):26-33.

62. He L, He X, Lim LP, de Stanchina E, Xuan Z, Liang Y, et al. A microRNA component of the p53 tumour suppressor network. Nature. 2007:447(7148):1130-4.

63. Yamakuchi M, Lowenstein CJ. MiR-34, SIRT1 and p53: the feedback loop. Cell Cycle. 2009;8(5):712-5.

64. Craig VJ, Tzankov A, Flori M, Schmid CA, Bader AG, Muller A. Systemic microRNA-34a delivery induces apoptosis and abrogates growth of diffuse large B-cell lymphoma in vivo. Leukemia. 2012;26(11):2421-4.

65. Huang $Y$, Zou Y, Lin L, Ma X, Zheng R. miR101 regulates the cell proliferation and apoptosis in diffuse large Bcell lymphoma by targeting MEK1 via regulation of the ERK/MAPK signaling pathway. Oncol Rep. 2019: 41(1):377-86.

66. Navarro A, Gaya A, Martinez A, Urbano-Ispizua A, Pons A, Balague O, et al. MicroRNA expression profiling in classic Hodgkin lymphoma. Blood. 2008; 111(5):2825-32.

67. Lawrie $\mathrm{CH}$, Chi J, Taylor S, Tramonti D, Ballabio E, Palazzo S, et al. Expression of microRNAs in diffuse large B cell lymphoma is associated with immunophenotype, survival and transformation from follicular lymphoma. J Cell Mol Med. 2009;13(7):1248-60.

68. labal J, Shen Y, Liu Y, Fu K, Jaffe ES, Liu C, et al. Genome-wide miRNA profiling of mantle cell lymphoma reveals a distinct subgroup with poor prognosis. Blood. 2012;119(21):4939-48.

69. Pasqualucci L, Dalla-Favera R. The genetic landscape of diffuse large B-cell lymphoma. Semin Hematol. 2015;52(2):67-76.

70. Boyle EM, Davies FE, Leleu X, Morgan GJ. Understanding the multiple biological aspects leading to myeloma. Haematologica. 2014;99(4):605-12.

71. Vicente-Duenas C, Romero-Camarero I, Gonzalez-Herrero I, Alonso-Escudero E, Abollo-Jimenez F, Jiang $X$, et al. A novel molecular mechanism involved in multiple myeloma development revealed by targeting MafB to haematopoietic progenitors. EMBO J. 2012;31(18):3704-17.
72. Hideshima T, Cottini F, Nozawa Y, Seo HS, Ohguchi H, Samur MK, et al. p53related protein kinase confers poor prognosis and represents a novel therapeutic target in multiple myeloma. Blood. 2017;129(10):1308-19.

73. Herrero AB, Rojas EA, Misiewicz-Krzeminska I, Krzeminski P, Gutierrez NC Molecular Mechanisms of p53 Deregulation in Cancer: An Overview in Multiple Myeloma. Int J Mol Sci. 2016;17(12)

74. Shaham L, Binder V, Gefen N, Borkhardt A, Izraeli S. MiR-125 in normal and malignant hematopoiesis. Leukemia. 2012;26(9):2011-8.

75. Murray MY, Rushworth SA, Zaitseva L, Bowles KM, Macewan DJ. Attenuation of dexamethasone-induced cell death in multiple myeloma is mediated by miR-125b expression. Cell Cycle. 2013;12(13):2144-53.

76. Zhou M, Liu ZX, Zhao YH, Ding Y, Liu H, Xi YG, et al. MicroRNA-125b confers the resistance of breast Cancer cells to paclitaxel through suppression of pro-apoptotic Bcl-2 antagonist killer 1 (Bak1) expression. J Biol Chem. 2010; 285(28):21496-507.

77. Abdi J, Rastgoo N, Li L, Chen W, Chang H. Role of tumor suppressor p53 and micro-RNA interplay in multiple myeloma pathogenesis. J Hematol Oncol. 2017;10(1):169.

78. Yuan J, Su Z, Gu W, Shen X, Zhao Q, Shi L, et al. MiR-19b and miR-20a suppress apoptosis, promote proliferation and induce tumorigenicity of multiple myeloma cells by targeting PTEN. Cancer Biomark. 2019:24(3):279-89.

79. Huang G, Liu X, Zhao X, Zhao J, Hao J, Ren J, et al. MiR-9 promotes multiple myeloma progression by regulating TRIM56/NF-kappaB pathway. Cell Biol Int. 2019. https://doi.org/10.1002/cbin.11104.

80. Rothfield N. Clinical aspects and treatment of systemic lupus erythematosus. Curr Opin Rheumatol. 1989;1(3):327-31.

81. Kil LP, Hendriks RW. Aberrant B cell selection and activation in systemic lupus erythematosus. Int Rev Immunol. 2013;32(4):445-70.

82. Dai $Y$, Huang YS, Tang M, Lv TY, Hu CX, Tan YH, et al. Microarray analysis of microRNA expression in peripheral blood cells of systemic lupus erythematosus patients. Lupus. 2007;16(12):939-46.

83. Wu XN, Ye YX, Niu JW, Li Y, Li X, You X, et al. Defective PTEN regulation contributes to $B$ cell hyperresponsiveness in systemic lupus erythematosus. Sci Transl Med. 2014;6(246):246ra99.

84. Sarhan RA, Aboelenein HR, Sourour SK, Fawzy IO, Salah S, Abdelaziz Al. Targeting E2F1 and c-Myc expression by microRNA-17-5p represses interferonstimulated gene MxA in peripheral blood mononuclear cells of pediatric systemic lupus erythematosus patients. Discov Med. 2015;19(107):419-25.

85. Zhang HD, Huang XX, Ye LL, Guo GQ, Li X, Chen CS, et al. B cell-related circulating MicroRNAs with the potential value of biomarkers in the differential diagnosis, and Distinguishment between the disease activity and lupus nephritis for systemic lupus erythematosus. Front Immunol. 2018:9:1473.

86. Zeng L, Wu JL, Liu LM, Jiang JQ, Wu HJ, Zhao M, et al. Serum miRNA-371b$5 p$ and miRNA-5100 act as biomarkers for systemic lupus erythematosus. Clin Immunol. 2018;196:103-9.

87. Iorio MV, Croce CM. MicroRNA dysregulation in cancer: diagnostics, monitoring and therapeutics. A comprehensive review. EMBO Mol Med. 2012:4(3):143-59.

88. Li Z, Rana TM. Therapeutic targeting of microRNAs: current status and future challenges. Nat Rev Drug Discov. 2014;13(8):622-38,

89. Babar IA, Cheng CJ, Booth CJ, Liang X, Weidhaas JB, Saltzman WM, et al. Nanoparticle-based therapy in an in vivo microRNA-155 (miR-155)dependent mouse model of lymphoma. Proc Natl Acad Sci U S A. 2012 109(26):E1695-704.

90. Misso G, Di Martino MT, De Rosa G, Faroogi AA, Lombardi A, Campani V, et al. Mir-34: a new weapon against cancer? Mol Ther Nucleic Acids. 2014;3:e194.

91. Trang P, Wiggins JF, Daige $C L$, Cho C, Omotola M, Brown D, et al. Systemic delivery of tumor suppressor microRNA mimics using a neutral lipid emulsion inhibits lung tumors in mice. Mol Ther. 2011;19(6):1116-22.

92. Wiggins JF, Ruffino L, Kelnar K, Omotola M, Patrawala L, Brown D, et al. Development of a lung cancer therapeutic based on the tumor suppressor microRNA-34. Cancer Res. 2010;70(14):5923-30.

93. Liu C, Kelnar K, Liu B, Chen X, Calhoun-Davis T, Li H, et al. The microRNA miR-34a inhibits prostate cancer stem cells and metastasis by directly repressing CD44. Nat Med. 2011;17(2):211-5.

94. Chakraborty C, Sharma AR, Sharma G, Doss CGP, Lee SS. Therapeutic miRNA and siRNA: moving from bench to clinic as next generation medicine. Mol Ther-Nucl Acids. 2017:8:132-43.

95. Geary RS, Watanabe TA, Truong L, Freier S, Lesnik EA, Sioufi NB, et al. Pharmacokinetic properties of 2'-O-(2-methoxyethyl)-modified oligonucleotide analogs in rats. J Pharmacol Exp Ther. 2001;296(3):890-7. 
96. Broderick JA, Zamore PD. MicroRNA therapeutics. Gene Ther. 2011;18(12):1104-10.

97. Jiang Y, Dominguez PM, Melnick AM. The many layers of epigenetic dysfunction in B-cell lymphomas. Curr Opin Hematol. 2016;23(4):377-84.

98. Shaknovich R, Cerchietti L, Tsikitas L, Kormaksson M, De S, Fiqueroa ME, et al. DNA methyltransferase 1 and DNA methylation patterning contribute to germinal center B-cell differentiation. Blood. 2011;118(13):3559-69.

99. Hung KH, Woo YH, Lin IY, Liu CH, Wang LC, Chen HY, et al. The KDM4A/ KDM4C/NF-kappaB and WDR5 epigenetic cascade regulates the activation of B cells. Nucleic Acids Res. 2018;46(11):5547-60.

100. Azagra A, Roman-Gonzalez L, Collazo O, Rodriguez-Ubreva J, de Yebenes VG, Barneda-Zahonero B, et al. In vivo conditional deletion of HDAC7 reveals its requirement to establish proper $B$ lymphocyte identity and development. J Exp Med. 2016;213(12):2591-601.

101. Kalushkova A, Fryknas M, Lemaire M, Fristedt C, Agarwal P, Eriksson M, et al. Polycomb target genes are silenced in multiple myeloma. PLoS One. 2010; 5(7):e11483

102. Raaphorst FM, van Kemenade FJ, Fieret E, Hamer KM, Satijn DP, Otte AP, et al. Cutting edge: polycomb gene expression patterns reflect distinct $\mathrm{B}$ cell differentiation stages in human germinal centers. J Immunol. 2000;164(1):1-4.

103. Caganova M, Carrisi C, Varano G, Mainoldi F, Zanardi F, Germain PL, et al. Germinal center dysregulation by histone methyltransferase EZH2 promotes lymphomagenesis. J Clin Invest. 2013;123(12):5009-22.

104. Chen HT, Bhandoola A, Difilippantonio MJ, Zhu J, Brown MJ, Tai X, et al. Response to RAG-mediated VDJ cleavage by NBS1 and gamma-H2AX. Science. 2000;290(5498):1962-5.

105. Petersen S, Casellas R, Reina-San-Martin B, Chen HT, Difilippantonio MJ, Wilson $P C$, et al. AID is required to initiate Nbs $1 /$ gamma-H2AX focus formation and mutations at sites of class switching. Nature. 2001;414(6864):660-5.

106. Odegard VH, Kim ST, Anderson SM, Shlomchik MJ, Schatz DG. Histone modifications associated with somatic hypermutation. Immunity. 2005;23(1): 101-10.

107. Fujimura S, Matsui T, Kuwahara K, Maeda K, Sakaguchi N. Germinal center Bcell-associated DNA hypomethylation at transcriptional regions of the AID gene. Mol Immunol. 2008;45(6):1712-9.

108. Crouch EE, Li Z, Takizawa M, Fichtner-Feigl S, Gourzi P, Montano C, et al. Regulation of AID expression in the immune response. J Exp Med. 2007; 204(5):1145-56.

109. Begum NA, Stanlie A, Nakata M, Akiyama H, Honjo T. The histone chaperone Spt6 is required for activation-induced cytidine deaminase target determination through H3K4me3 regulation. J Biol Chem. 2012;287(39): 32415-29.

110. Borchert GM, Holton NW, Edwards KA, Vogel LA, Larson ED. Histone H2A and $\mathrm{H} 2 \mathrm{~B}$ are monoubiquitinated at AID-targeted loci. PLoS One. 2010;5(7): e11641.

111. Baxter J, Sauer S, Peters A, John R, Williams R, Caparros ML, et al. Histone hypomethylation is an indicator of epigenetic plasticity in quiescent lymphocytes. EMBO J. 2004;23(22):4462-72.

112. Ruthenburg AJ, Wang W, Graybosch DM, Li H, Allis CD, Patel DJ, et al. Histone H3 recognition and presentation by the WDR5 module of the MLL1 complex. Nat Struct Mol Biol. 2006;13(8):704-12.

113. Shi W, Liao Y, Willis SN, Taubenheim N, Inouye M, Tarlinton DM, et al. Transcriptional profiling of mouse B cell terminal differentiation defines a signature for antibody-secreting plasma cells. Nat Immunol. 2015;16(6):663-73.

114. Ochiai K, Muto A, Tanaka H, Takahashi S, Igarashi K. Regulation of the plasma cell transcription factor Blimp-1 gene by Bach2 and Bcl6. Int Immunol. 2008;20(3):453-60.

115. Lemercier C, Brocard MP, Puvion-Dutilleul F, Kao HY, Albagli O, Khochbin S Class II histone deacetylases are directly recruited by BCL6 transcriptional repressor. J Biol Chem. 2002;277(24):22045-52.

116. Lee SC, Bottaro A, Insel RA. Activation of terminal B cell differentiation by inhibition of histone deacetylation. Mol Immunol. 2003;39(15):923-32.

117. Su ST, Ying HY, Chiu YK, Lin FR, Chen MY, Lin Kl. Involvement of histone demethylase LSD1 in Blimp-1-mediated gene repression during plasma cell differentiation. Mol Cell Biol. 2009;29(6):1421-31.

118. Yu J, Angelin-Duclos C, Greenwood J, Liao J, Calame K. Transcriptional repression by blimp-1 (PRDI-BF1) involves recruitment of histone deacetylase. Mol Cell Biol. 2000;20(7):2592-603.

119. Czermin B, Melfi R, McCabe D, Seitz V, Imhof A, Pirrotta V. Drosophila enhancer of Zeste/ESC complexes have a histone H3 methyltransferase activity that marks chromosomal Polycomb sites. Cell. 2002;111(2):185-96.
120. Beguelin W, Popovic R, Teater M, Jiang Y, Bunting KL, Rosen M, et al. EZH2 is required for germinal center formation and somatic EZH2 mutations promote lymphoid transformation. Cancer Cell. 2013;23(5):677-92.

121. Morin RD, Johnson NA, Severson TM, Mungall AJ, An J, Goya R, et al. Somatic mutations altering EZH2 (Tyr641) in follicular and diffuse large Bcell lymphomas of germinal-center origin. Nat Genet. 2010;42(2):181-5.

122. Shilatifard A. The COMPASS family of histone H3K4 methylases: mechanisms of regulation in development and disease pathogenesis. Annu Rev Biochem. 2012;81:65-95.

123. Ortega-Molina A, Boss IW, Canela A, Pan H, Jiang Y, Zhao C, et al. The histone lysine methyltransferase KMT2D sustains a gene expression program that represses B cell lymphoma development. Nat Med. 2015;21(10):1199-208.

124. Zhang J, Dominguez-Sola D, Hussein S, Lee JE, Holmes AB, Bansal M, et al. Disruption of KMT2D perturbs germinal center $B$ cell development and promotes lymphomagenesis. Nat Med. 2015;21(10):1190-8.

125. Wang Z, Zang C, Rosenfeld JA, Schones DE, Barski A, Cuddapah S, et al. Combinatorial patterns of histone acetylations and methylations in the human genome. Nat Genet. 2008;40(7):897-903.

126. Lunning MA, Green MR. Mutation of chromatin modifiers; an emerging hallmark of germinal center B-cell lymphomas. Blood Cancer J. 2015;5:e361.

127. Pasqualucci L, Dominguez-Sola D, Chiarenza A, Fabbri G, Grunn A, Trifonov $V$, et al. Inactivating mutations of acetyltransferase genes in B-cell lymphoma. Nature. 2011;471(7337):189-95.

128. Zhang J, Vlasevska S, Wells VA, Nataraj S, Holmes AB, Duval R, et al. The CREBBP acetyltransferase is a Haploinsufficient tumor suppressor in B-cell lymphoma. Cancer Discov. 2017;7(3):322-37.

129. Rollig C, Knop S, Bornhauser M. Multiple myeloma. Lancet. 2015;385(9983): 2197-208.

130. Avet-Loiseau H, Leleu X, Roussel M, Moreau P, Guerin-Charbonnel C, Caillot $D$, et al. Bortezomib plus dexamethasone induction improves outcome of patients with $\mathrm{t}(4 ; 14)$ myeloma but not outcome of patients with del(17p). J Clin Oncol. 2010;28(30):4630-4.

131. Kuo AJ, Cheung P, Chen K, Zee BM, Kioi M, Lauring J, et al. NSD2 links dimethylation of histone $\mathrm{H} 3$ at lysine 36 to oncogenic programming. Mol Cell. 2011;44(4):609-20.

132. Pei H, Zhang L, Luo K, Qin Y, Chesi M, Fei F, et al. MMSET regulates histone H4K20 methylation and 53BP1 accumulation at DNA damage sites. Nature. 2011:470(7332):124-8

133. Martinez-Garcia E, Popovic R, Min DJ, Sweet SM, Thomas PM, Zamdborg L, et al. The MMSET histone methyl transferase switches global histone methylation and alters gene expression in $\mathrm{t}(4 ; 14)$ multiple myeloma cells. Blood. 2011;117(1):211-20.

134. Marango J, Shimoyama M, Nishio H, Meyer JA, Min DJ, Sirulnik A, et al. The MMSET protein is a histone methyltransferase with characteristics of a transcriptional corepressor. Blood. 2008:111(6):3145-54.

135. Min DJ, Ezponda T, Kim MK, Will CM, Martinez-Garcia E, Popovic R, et al, MMSET stimulates myeloma cell growth through microRNA-mediated modulation of c-MYC. Leukemia. 2013;27(3):686-94.

136. Pawlyn C, Bright MD, Buros AF, Stein CK, Walters Z, Aronson LI, et al. Overexpression of $\mathrm{EZ} \mathrm{H} 2$ in multiple myeloma is associated with poor prognosis and dysregulation of cell cycle control. Blood Cancer J. 2017;7(3):e549.

137. Agarwal $P$, Alzrigat M, Parraga AA, Enroth S, Singh U, Ungerstedt J, et al. Genome-wide profiling of histone H3 lysine 27 and lysine 4 trimethylation in multiple myeloma reveals the importance of Polycomb gene targeting and highlights EZH2 as a potential therapeutic target. Oncotarget. 2016;7(6): 6809-23.

138. Pawlyn C, Kaiser MF, Heuck C, Melchor L, Wardell CP, Murison A, et al. The Spectrum and clinical impact of epigenetic modifier mutations in myeloma. Clin Cancer Res. 2016:22(23):5783-94

139. van Haaften G, Dalgliesh GL, Davies H, Chen L, Bignell G, Greenman C, et al. Somatic mutations of the histone H3K27 demethylase gene UTX in human cancer. Nat Genet. 2009:41(5):521-3.

140. Ezponda T, Dupere-Richer D, Will CM, Small EC, Varghese N, Patel T, et al. UTX/KDM6A loss enhances the malignant phenotype of multiple myeloma and sensitizes cells to EZH2 inhibition. Cell Rep. 2017;21(3):628-40.

141. Ohguchi H, Hideshima T, Bhasin MK, Gorgun GT, Santo L, Cea M, et al. The KDM3AKLF2-IRF4 axis maintains myeloma cell survival. Nat Commun. 2016;7:10258.

142. Uemura M, Yamamoto H, Takemasa I, Mimori K, Hemmi H, Mizushima T, et al. Jumonji domain containing $1 \mathrm{~A}$ is a novel prognostic marker for colorectal cancer: in vivo identification from hypoxic tumor cells. Clin Cancer Res. 2010;16(18):4636-46. 
143. Cho SF, Chang YC, Chang CS, Lin SF, Liu YC, Hsiao HH, et al. MALAT1 long non-coding RNA is overexpressed in multiple myeloma and may serve as a marker to predict disease progression. BMC Cancer. 2014;14:809.

144. Handa H, Kuroda Y, Kimura K, Masuda Y, Hattori H, Alkebsi L, et al. Long non-coding RNA MALAT1 is an inducible stress response gene associated with extramedullary spread and poor prognosis of multiple myeloma. $\mathrm{Br} J$ Haematol. 2017;179(3):449-60.

145. Nawrocki MJ, Majewski D, Puszczewicz M, Jagodzinski PP. Decreased mRNA expression levels of DNA methyltransferases type 1 and $3 A$ in systemic lupus erythematosus. Rheumatol Int. 2017;37(5):775-83.

146. Garaud S, Le Dantec C, Jousse-Joulin S, Hanrotel-Saliou C, Saraux A, Mageed RA, et al. IL-6 modulates CD5 expression in B cells from patients with lupus by regulating DNA methylation. J Immunol. 2009;182(9):5623-32.

147. Hippen $K L$, Tze LE, Behrens TW. CD5 maintains tolerance in anergic B cells. J Exp Med. 2000;191(5):883-90.

148. Nakkuntod J, Avihingsanon Y, Mutirangura A, Hirankarn N. Hypomethylation of LINE-1 but not Alu in lymphocyte subsets of systemic lupus erythematosus patients. Clin Chim Acta. 2011;412(15-16):1457-61.

149. Fali T, Le Dantec C, Thabet Y, Jousse S, Hanrotel C, Youinou P, et al. DNA methylation modulates HRES1/p28 expression in B cells from patients with lupus. Autoimmunity. 2014;47(4):265-71.

150. Silverman LR, Demakos EP, Peterson BL, Kornblith AB, Holland JC, OdchimarReissig $\mathrm{R}$, et al. Randomized controlled trial of azacitidine in patients with the myelodysplastic syndrome: a study of the cancer and leukemia group B. J Clin Oncol. 2002;20(10):2429-40.

151. Kantarjian H, Issa JP, Rosenfeld CS, Bennett JM, Albitar M, DiPersio J, et al. Decitabine improves patient outcomes in myelodysplastic syndromes: results of a phase III randomized study. Cancer. 2006;106(8):1794-803.

152. Kiziltepe T, Hideshima T, Catley L, Raje N, Yasui H, Shiraishi N, et al. 5-Azacytidine, a DNA methyltransferase inhibitor, induces ATR-mediated DNA double-strand break responses, apoptosis, and synergistic cytotoxicity with doxorubicin and bortezomib against multiple myeloma cells. Mol Cancer Ther. 2007;6(6):1718-27.

153. Cao Y, Qiu GQ, Wu HQ, Wang ZL, Lin Y, Wu W, et al. Decitabine enhances bortezomib treatment in RPMI 8226 multiple myeloma cells. Mol Med Rep. 2016;14(4):3469-75.

154. New M, Olzscha H, La Thangue NB. HDAC inhibitor-based therapies: can we interpret the code? Mol Oncol. 2012;6(6):637-56.

155. Seidel C, Schnekenburger M, Dicato M, Diederich M. Histone deacetylase 6 in health and disease. Epigenomics. 2015;7(1):103-18.

156. Hideshima T, Qi J, Paranal RM, Tang W, Greenberg E, West N, et al. Discovery of selective small-molecule HDAC6 inhibitor for overcoming proteasome inhibitor resistance in multiple myeloma. Proc Natl Acad Sci U S A. 2016;113(46):13162-7.

157. Santo L, Hideshima T, Kung AL, Tseng JC, Tamang D, Yang M, et al. Preclinical activity, pharmacodynamic, and pharmacokinetic properties of a selective HDAC6 inhibitor, ACY-1215, in combination with bortezomib in multiple myeloma. Blood. 2012;119(11):2579-89.

158. Galli M, Salmoiraghi S, Golay J, Gozzini A, Crippa C, Pescosta N, et al. A phase II multiple dose clinical trial of histone deacetylase inhibitor ITF2357 in patients with relapsed or progressive multiple myeloma. Ann Hematol. 2010;89(2):185-90

159. Richardson PG, Hungria VT, Yoon SS, Beksac M, Dimopoulos MA, Elghandour A, et al. Panobinostat plus bortezomib and dexamethasone in previously treated multiple myeloma: outcomes by prior treatment. Blood. 2016;127(6):713-21.

160. Dupere-Richer D, Licht JD. Epigenetic regulatory mutations and epigenetic therapy for multiple myeloma. Curr Opin Hematol. 2017:24(4):336-44.

161. Chaidos A, Caputo V, Gouvedenou K, Liu B, Marigo I, Chaudhry MS, et al. Potent antimyeloma activity of the novel bromodomain inhibitors I-BET151 and I-BET762. Blood. 2014;123(5):697-705.

162. Siu KT, Ramachandran J, Yee AJ, Eda H, Santo L, Panaroni C, et al. Preclinical activity of CPI-0610, a novel small-molecule bromodomain and extraterminal protein inhibitor in the therapy of multiple myeloma. Leukemia. 2017;31(8):1760-9.

163. Amorim S, Stathis A, Gleeson M, lyengar S, Magarotto V, Leleu X, et al. Bromodomain inhibitor OTX015 in patients with lymphoma or multiple myeloma: a dose-escalation, open-label, pharmacokinetic, phase 1 study. Lancet Haematol. 2016:3(4):e196-204.
164. Alzrigat M, Jernberg-Wiklund H, Licht JD. Targeting EZH2 in Multiple Myeloma-Multifaceted Anti-Tumor Activity. Epigenomes. 2018;2(3). https:// doi.org/10.3390/epigenomes2030016.

165. Zeng D, Liu M, Pan J. Blocking EZH2 methylation transferase activity by GSK126 decreases stem cell-like myeloma cells. Oncotarget. 2017;8(2):3396-411.

\section{Publisher's Note}

Springer Nature remains neutral with regard to jurisdictional claims in published maps and institutional affiliations.
Ready to submit your research? Choose BMC and benefit from:

- fast, convenient online submission

- thorough peer review by experienced researchers in your field

- rapid publication on acceptance

- support for research data, including large and complex data types

- gold Open Access which fosters wider collaboration and increased citations

- maximum visibility for your research: over $100 \mathrm{M}$ website views per year

At BMC, research is always in progress.

Learn more biomedcentral.com/submissions 